\title{
Resource Use Efficiency in Pineapple Cultivation - a Case Study from Manipur, India
}

\author{
Laxmi Thingbaijam ${ }^{1}$, K. K. Das ${ }^{1 *}$, N. R. Singh ${ }^{2}$ and S. Zimisai ${ }^{1}$ \\ ${ }^{1}$ Dept. of Agricultural Economics, Uttar Banga Krishi Vishwa Vidyalaya, Pundibari, CoochBehar, West Bengal (736 165), India \\ ${ }^{2}$ Dept. of Agril. Economics, Central Agricultural University, Imphal, Manipur (795 004), India
}

\section{Article History}

Manuscript No. AR849

Received in $18^{\text {th }}$ July, 2014

Received in revised form $18^{\text {th }}$ May, 2015

Accepted in final form $7^{\text {th }}$ June, 2015

\section{Correspondence to}

"E-mail: daskk3@gmail.com

\section{Keywords}

Pineapple, resource use efficiency, production function, benefit-cost ratio

\begin{abstract}
The study analysed the resource use efficiency of pineapple (Ananus comosus) by using Cobb-Douglas production function with a unique set of 100 randomly selected sample farmers of Manipur district during 2009-10. The pineapple can be a good economic activity of Manipur. Farmers could earn net income of ₹ 1,73,312.20 (\$2888.54) $\mathrm{ha}^{-1}$. With a satisfactory benefit-cost ratio of 4.05 . The average cost of cultivation was ₹ 57303.02 (\$955.05) ha-1. Small farmers (category-I) were found to have more profit compared to big farmers (Category-II). This could be justified with the higher values of their resource use efficiency in respect of planting material (sucker), plant protection chemical, manure and fertilizers etc. Production function analysis identified expenditure on sucker, manures and fertilizers, plant protection chemicals, labour wage being the major cost components. Marginal value product (MVP) analysis also collaborated these findings. Judicious use of sucker, plant protection chemicals and manures and fertilizers had been found to have good and positive impact on production and the net return. Use of excess human labour made the farming less remunerative which advocated engagement of labour at optimal level.
\end{abstract}

\section{Introduction}

Pineapple (Ananus comosus) is one of the most important commercial fruits of the world. It covers about $25 \%$ of global production of tropical fruits (Yacob, 2010). Worldwide, about 82 countries produce pineapple in economic quantities. Thailand, Brazil, India, Nigeria, Philippines, China are the major pineapple producing countries in the world. India is an important player in pineapple trade being contributing an area of 105 thousands ha with a production of 1571 thousands MT (Hand Book on Horticulture Statistics 2014). Pineapple is a good source of Vitamin A, B, C and also calcium, magnesium, potassium and iron. It is also a good source of bromelin, a digestive enzyme.

Pineapple is widely grown in the hills of North Eastern Region of India from the time immemorial. The region with 57.3 thousand ha and production of 662.49 thousand MT, contributes about $64.4 \%$ and $46.81 \%$ of country's pineapple area and production respectively (Indian Horticulture Database, 2011). Manipur is one of the leading pineapple producing States in North-Eastern region owing to its salubrious climate and soil type and it contributes about $21.29 \%$ and $16.69 \%$ of region's pineapple area and production respectively. Among the fruits produced in Manipur, pineapple records the largest production contributing to about $38.63 \%$ of total fruit production during the year 2010-11. The prevailing wide agro-climatic conditions of Manipur make it possible to cultivate pineapple throughout the year. It has an average temperature of $20.36{ }^{\circ} \mathrm{C}$ and receives excellent sunshine during summer and winter season. Pineapple has been cultivated in all the 9 (nine) districts of Manipur. Kew and Queen are the most prevalent pineapple variety cultivated in Manipur. Economically, the fruit has become the backbone of a sizeable section of farmers who have been cultivating it as their major source of income. Pineapple cultivation can be an alternative industry for generating large employment and major source of income in Manipur. The cultivation of pineapple opens up new avenues for employment and income to the farming folk in Manipur. Table 1 indicates that there is an increasing trend in area of India and Manipur over the period of the study 2001-2014 but production and productivity are fluctuating over the same period. The same data had been represented in Figure 1(a), 1(b) and 1(c) for area, production and productivity of India and Manipur respectively.

This shows that there is an evident of variation in trend line of area, production and productivity of pineapple in India and Manipur. It is held that variation and inefficiency in input use 
are inter alia remains to be important determining factors of crop productivity under the given set of ecological management and technological conditions at a particular point of time. Keeping all these in view, the research problem is identified and taken up with the following objectives.

\begin{tabular}{|c|c|c|c|c|c|c|}
\hline \multicolumn{7}{|c|}{$\begin{array}{l}\text { Table 1: Area, produc } \\
\text { Manipur and India }\end{array}$} \\
\hline \multirow[t]{2}{*}{ Year } & \multicolumn{2}{|c|}{ Area (000 ha) } & \multicolumn{2}{|c|}{$\begin{array}{l}\text { Production } \\
(000 \mathrm{t})\end{array}$} & \multicolumn{2}{|c|}{$\begin{array}{l}\text { Productivity } \\
\quad\left(\mathrm{t} \mathrm{ha}^{-1}\right)\end{array}$} \\
\hline & India & $\begin{array}{l}\text { Ma- } \\
\text { nipur }\end{array}$ & India & $\begin{array}{l}\text { Ma- } \\
\text { nipur }\end{array}$ & India & $\begin{array}{l}\text { Ma- } \\
\text { nipur }\end{array}$ \\
\hline 2001-02 & 77.2 & 10.08 & 1182.1 & 69.43 & 15.30 & 6.89 \\
\hline 2002-03 & 79.8 & 10.33 & 1171.7 & 75.58 & 14.70 & 7.32 \\
\hline 2003-04 & 80.9 & 10.65 & & & 15.30 & 7.50 \\
\hline 2004-05 & 82.8 & 11.87 & 1278.9 & 95.43 & 15.40 & 8.04 \\
\hline 2005-06 & 82.4 & 11.87 & 1262.6 & 97.52 & 15.30 & 8.21 \\
\hline 2006-07 & 87.0 & 11.99 & 1362 & 100.68 & 15.70 & 8.40 \\
\hline 2007-08 & 80.0 & 12.05 & 1245 & 102.61 & 15.60 & 8.52 \\
\hline 2008-09 & 84.0 & 12.05 & 1341 & 109.52 & 16.00 & 9.09 \\
\hline 2009-10 & 91.9 & 12.05 & 1386.8 & 71.71 & 15.10 & 5.95 \\
\hline 2010-11 & 89.0 & 12.12 & 1415 & 110.60 & 15.90 & 9.13 \\
\hline 2011-12 & 102.0 & 12.6 & 1500 & 116.60 & 14.71 & 9.30 \\
\hline $2012-13$ & 105.0 & 13.06 & 1571 & 124.14 & 14.96 & 9.51 \\
\hline 2013-14 & 109.9 & 13.7 & 1736.7 & 136.31 & 15.80 & 9.90 \\
\hline
\end{tabular}

Source : Directorate of economics and statistics : Government of Manipur

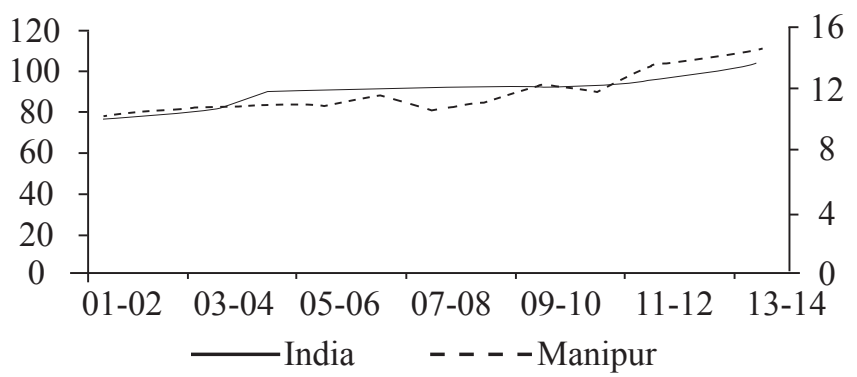

Figure 1.a: Pineapple area (000 ha): India and Manipur

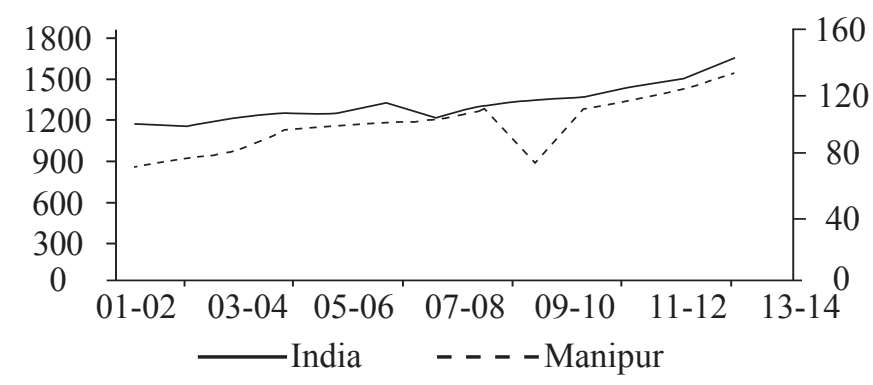

Figure 1.b: Pineapple production (000 t): India and Manipur

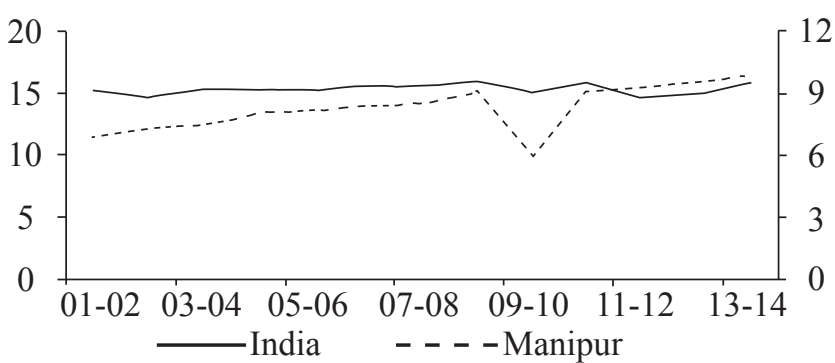

Figure 1.c: Pineapple productivity $\left(\mathrm{t} \mathrm{ha}^{-1}\right)$

a. to find out the 'economics' of pineapple cultivation in accordance with size of farming.

b. to identify the important input factors,

c. to estimate the resource use efficiency of significant input factors and

d. to suggest important input factors for increasing the resource use efficiency.

\section{Materials and Methods}

Thoubal district of Manipur was selected purposively in consultation with Agricultural Development Officers and Gram Panchayat members. Data were collected from 100 sample farmers of 4 villages of Thoubal districts in which probability proportional sampling technique has been adopted. The farmers were grouped in two categories i.e. category-I (having $<1.0$ ha of pineapple orchard) and category-II (having $\geq 1.0$ ha of pineapple orchard). Data pertained to agricultural year 2009-10. Usual technique of Farm Management (Kahlon and Singh, 1992) was followed while calculating costs and returns structure of pineapple production.

For easy understanding and convenience of study only Cost $\mathrm{A}_{1}$ and $\operatorname{Cost} \mathrm{C}_{3}$ had been considered for analysis computation of which is as follows :

Cost $A_{1}=$ It includes all paid out costs in terms of costs of sucker, manure and fertilizer, plant protection chemical, hired human labour, depreciation, land revenue, interest on working capital and miscellaneous expenses.

Cost $\mathrm{C}_{3}$ (Total Cost) $=\mathrm{It}$ includes $\operatorname{Cost}_{1}$ and other imputed costs and adding to it $10 \%$ as managerial costs.

Return analysis had been done with the help of the following formula (absolute and ratio method).

i. Net farm income (NFI) $=$ Gross Farm Income (GFI)-Cost $\mathrm{C}_{3}$ ii. Farm business income $=$ Gross Farm Income (GFI)-Cost $\mathrm{A}_{1}$ iii. Output-Input Ratio (on the basis of Total Cost) $=\mathrm{GFI} / \mathrm{Cost}_{3}$ iv. Output-Input Ratio (on the basis of paid out Cost) $=\mathrm{GFI} /$ Cost $\mathrm{A}_{1}$

The production function approach was used for studying the relationship between the output and input variables of pineapple production. Resource use efficiency was examined by using Cobb Douglas type of production function. The model 
estimated form has been illustrated below:

$\mathrm{Y}=\mathrm{b}_{0} \mathrm{x}_{\mathrm{i}}{ }^{\mathrm{b}} \mathrm{e}^{\mathrm{u}} \quad$ In $\mathrm{y}=\operatorname{In} \mathrm{b}+\mathrm{b}_{\mathrm{i}}$ In $\mathrm{x}_{\mathrm{i}}$

Or, In $y=\operatorname{In~} b_{0}+b_{1} \operatorname{In} x_{1}+b_{2} \operatorname{In} x_{2}+b_{3} \operatorname{In} x_{3}+b_{4} \ln x_{4}$

Where, $y=$ Total output $(₹)$; $x=$ Sucker $(₹)$; $x=$ Expenses on manure and fertilizer $(₹)$; $\mathrm{x}_{3}=$ Expenses on plant protection chemical (₹); $x=$ Human labour $(₹)$; $b_{0}=$ Constant term; $b_{i}=$ Elasticity co-efficients $(i=1,2,3 \ldots n) ; e^{u}=$ Error term.

The resource use efficiency was studied only for those variables, which had a significant and positive effect on the dependent variable. Equality of marginal value product and marginal factor cost (i.e. $\mathrm{MVP} / \mathrm{MFC}=1$ ) indicates the optimum resource use efficiency for a particular input. Marginal value product and marginal factor cost ratio of an input were used to test the efficiency of the resource use which is given as:

Resource use efficiency $=\mathrm{MVP}_{\mathrm{xi}} / \mathrm{MFC}_{\mathrm{xi}}$

Where, $\mathrm{MVP}_{\mathrm{xi}}=$ Marginal value product of ith input and $\mathrm{MFC}_{\mathrm{xi}}=$ Marginal factor cost of ith input

\section{Results and Discussion}

\section{a. Socio-economic status}

Socio-economic transformation and adoption of innovations are greatly influenced by the age factor, particularly that of the decision makers. Age old decision making heads, in general, are presumed to be less dynamic and less innovative because of their multifarious social and family burden. Similarly, too young family head may be having the tendency of taking immature/rash decision (s). A close perusal of Table 2 reveals that most (about $83 \%$ ) of the respondent pineapple growers belong to the agegroup of 31-50 years and, therefore, having greater possibility of good adopting behavior towards improved cultivation techniques. There is no visible difference in between the categories of farming in this respect. But there seems to be a direct influence of size of pineapple orchard on the size of farm family as farmers of category II have relatively larger family size. Overall, the size of such farm family is around 5 .

The fact that about $85 \%$ of the farm family heads are literate is an encouraging picture (Table 3). More importantly, about $70 \%$ of them had post primary education, in general. Of course, higher educated farm family heads are much more in the category-I. Regarding size of pineapple orchard, the pineapple growers of category-I have about orchard size of 0.59 ha and those of category-
II have orchard size of 1.13 ha and average size of pineapple orchards was 0.85 ha.

\section{b. Estimated cost of cultivation of pineapple}

Table 4 shows the per hectare cost of cultivation of pineapple for different categories of sample farms. The overall per hectare average $\operatorname{cost}\left(\operatorname{Cost} \mathrm{C}_{3}\right)$ of cultivation is ₹ 57,303.02. However, total cost of cultivation on large farms (Category-II) was much higher (₹ 67,394.24) than that of small farms (₹ 47,211.8). Of this, the paid out cost $\left(\operatorname{Cost} A_{1}\right)$ happens to be ₹ 42,093.29 for category-II and ₹ 29,108.71 for category-I which is relatively small in any standard. Overall, cost of planting materials contributes about $38.94 \%$, manures and fertilizers contributes about $9.90 \%$ and hired human labour contributes about $35.11 \%$ of the paid out cost. Within the total cost of cultivation (i.e., Cost $\mathrm{C}_{3}$ ), imputed rental value for owned land was the major cost item for all the farms. It accounted for about 25.42 and $24.06 \%$ of the total cost of cultivation on category-I and category-II farms respectively.

\section{c. Farm efficiency measures of pineapple}

Table 5 presents the comparative status farms efficiency of the two farm categories as well as of all farm taken together. Based on the Cost $\mathrm{A}_{1}$, the gross farm income on category-II farm was higher than the category-I farm. Gross farm income of category-

\begin{tabular}{|c|c|c|c|c|c|c|c|}
\hline \multirow{2}{*}{$\begin{array}{l}\text { Farm- } \\
\text { ing } \\
\text { Cat- } \\
\text { egory }\end{array}$} & \multicolumn{2}{|c|}{$\begin{array}{l}\text { Percentage } \\
\text { of literacy } \\
\text { among farm } \\
\text { family heads }\end{array}$} & \multicolumn{4}{|c|}{$\begin{array}{c}\text { Percentage of farm family heads } \\
\text { with educational standard of }\end{array}$} & \multirow{2}{*}{$\begin{array}{l}\text { Size } \\
\text { of } \\
\text { hol- } \\
\text { dings } \\
\text { (ha.) }\end{array}$} \\
\hline & $\begin{array}{l}\text { Illit- } \\
\text { erate }\end{array}$ & $\begin{array}{l}\text { Lit- } \\
\text { erate }\end{array}$ & $\begin{array}{l}\text { Up-to } \\
\text { pri- } \\
\text { mary }\end{array}$ & $\begin{array}{l}\text { Stan- } \\
\text { dard } \\
\text { V to X }\end{array}$ & $\begin{array}{l}\text { Standard } \\
\text { XI to XII }\end{array}$ & $\begin{array}{l}\text { Gradu- } \\
\text { ate } \\
\text { and } \\
\text { above }\end{array}$ & \\
\hline $\begin{array}{l}\text { Cate- } \\
\text { gory I }\end{array}$ & 13.43 & 86.57 & 22.41 & 48.28 & 29.31 & 0.00 & 0.59 \\
\hline $\begin{array}{l}\text { Cate- } \\
\text { gory } \\
\text { II }\end{array}$ & 18.18 & 81.82 & 44.43 & 25.92 & 11.12 & 18.53 & 1.13 \\
\hline $\begin{array}{l}\text { Over- } \\
\text { all }\end{array}$ & 15.00 & 85.00 & 29.41 & 41.18 & 23.53 & 5.88 & 0.85 \\
\hline
\end{tabular}

\begin{tabular}{lcccccccc}
\hline \multicolumn{2}{l}{ Table 2: Age and family composition of pineapple growers } \\
\hline $\begin{array}{l}\text { Farming } \\
\text { category }\end{array}$ & \multicolumn{2}{c}{ Percentage of farm family heads in the age group of } & \multicolumn{3}{c}{ Composition of farm family } \\
\cline { 2 - 9 } & Upto 30 years & $31-40$ years & $41-50$ years & Above 50 years & $\begin{array}{c}\text { Adult male } \\
\text { (nos.) }\end{array}$ & $\begin{array}{c}\text { Adult female } \\
\text { (nos.) }\end{array}$ & $\begin{array}{c}\text { Children } \\
\text { (nos.) }\end{array}$ & $\begin{array}{c}\text { Total } \\
\text { (nos.) }\end{array}$ \\
\hline Category I & 0.00 & 51.36 & 30.28 & 18.36 & 1.70 & 1.56 & 1.59 & 4.85 \\
Category II & 0.00 & 47.45 & 37.35 & 15.20 & 2.12 & 1.88 & 1.36 & 5.36 \\
Overall & 0.00 & 49.41 & 33.82 & 16.78 & 1.84 & 1.67 & 1.51 & 5.02 \\
\hline
\end{tabular}




\begin{tabular}{|c|c|c|c|c|}
\hline \multirow{2}{*}{$\begin{array}{l}\text { Sl. } \\
\text { no. }\end{array}$} & \multirow[t]{2}{*}{ Item of Cost } & \multicolumn{3}{|c|}{ Cost of cultivation } \\
\hline & & Category I & Category II & Overall \\
\hline 1. & Sucker & $\begin{array}{c}11513.42 \\
(24.39)\end{array}$ & $\begin{array}{c}16215.22 \\
(24.06)\end{array}$ & $\begin{array}{c}13864.32 \\
(24.19)\end{array}$ \\
\hline 2. & $\begin{array}{l}\text { Manure and } \\
\text { fertilizer }\end{array}$ & $\begin{array}{c}2989.39 \\
(6.33)\end{array}$ & $\begin{array}{c}4058.43 \\
(6.02)\end{array}$ & $\begin{array}{c}3523.91 \\
(6.15)\end{array}$ \\
\hline 3. & $\begin{array}{l}\text { Plant } \\
\text { protection } \\
\text { chemicals }\end{array}$ & $\begin{array}{l}332.27 \\
(0.70)\end{array}$ & $\begin{array}{c}468.32 \\
(0.69)\end{array}$ & $\begin{array}{c}400.29 \\
(0.70)\end{array}$ \\
\hline 4. & $\begin{array}{l}\text { Hired human } \\
\text { labour }\end{array}$ & $\begin{array}{c}10068.18 \\
(21.33)\end{array}$ & $\begin{array}{c}14929.72 \\
(22.15)\end{array}$ & $\begin{array}{c}12498.95 \\
(21.81)\end{array}$ \\
\hline 5. & $\begin{array}{l}\text { Interest on } \\
\text { working } \\
\text { capital }\end{array}$ & $\begin{array}{c}3486.46 \\
(7.38)\end{array}$ & $\begin{array}{c}4994.04 \\
(7.41)\end{array}$ & $\begin{array}{c}4240.25 \\
(7.40)\end{array}$ \\
\hline 6. & $\begin{array}{l}\text { Family } \\
\text { labour }\end{array}$ & $\begin{array}{l}174.17 \\
(0.37)\end{array}$ & $\begin{array}{l}442.65 \\
(0.66)\end{array}$ & $\begin{array}{c}308.41 \\
(0.54)\end{array}$ \\
\hline 7. & Depreciation & $\begin{array}{c}659 \\
(1.40)\end{array}$ & $\begin{array}{c}1346.47 \\
(2.00)\end{array}$ & $\begin{array}{c}1002.73 \\
(1.75)\end{array}$ \\
\hline 8. & $\begin{array}{l}\text { Land } \\
\text { revenue }\end{array}$ & $\begin{array}{c}60 \\
(0.13)\end{array}$ & $\begin{array}{l}81.08 \\
(0.12)\end{array}$ & $\begin{array}{l}70.54 \\
(0.12)\end{array}$ \\
\hline 9. & $\begin{array}{l}\text { Interest on } \\
\text { fixed capital }\end{array}$ & $\begin{array}{l}107.18 \\
(0.23)\end{array}$ & $\begin{array}{c}224.42 \\
(0.33)\end{array}$ & $\begin{array}{l}165.80 \\
(0.29)\end{array}$ \\
\hline 10. & $\begin{array}{l}\text { Imputed } \\
\text { rental value } \\
\text { of owned } \\
\text { land }\end{array}$ & $\begin{array}{l}12000 \\
(25.42)\end{array}$ & $\begin{array}{c}16215.22 \\
(24.06)\end{array}$ & $\begin{array}{c}14107.61 \\
(24.62)\end{array}$ \\
\hline 11. & $\begin{array}{l}\text { Managerial } \\
\text { cost }\end{array}$ & $\begin{array}{c}2910.87 \\
(6.17)\end{array}$ & $\begin{array}{c}4209.33 \\
(6.25)\end{array}$ & $\begin{array}{c}3560.10 \\
(6.21)\end{array}$ \\
\hline 12. & Risk margin & $\begin{array}{c}2910.87 \\
(6.17)\end{array}$ & $\begin{array}{c}4209.33 \\
(6.25)\end{array}$ & $\begin{array}{c}3560.10 \\
(6.21)\end{array}$ \\
\hline a) & $\operatorname{Cost} \mathrm{A}_{1}$ & $\begin{array}{c}29108.71 \\
{[\$ 485.15]}\end{array}$ & $\begin{array}{c}42093.29 \\
{[\$ 701.55]}\end{array}$ & $\begin{array}{c}35601.00 \\
{[\$ 593.35]}\end{array}$ \\
\hline b) & Cost $\mathrm{C}_{3}$ & $\begin{array}{c}47211.8 \\
{[\$ 786.86]} \\
\end{array}$ & $\begin{array}{c}67394.24 \\
{[\$ 1123.24]} \\
\end{array}$ & $\begin{array}{c}57303.02 \\
{[\$ 955.05]}\end{array}$ \\
\hline
\end{tabular}

NB: Figures in parentheses ( ) indicate percentage to total. Figures in parentheses [ ] indicate conversion of rupee into US $\$(1 \mathrm{US} \$=₹ 60,12 / 7 / 2014)$.

II farmers was ₹ 2, 62,377.30 comparing to ₹ $1,98,853.20$ of category-I farmers. On an average, pineapple growing farmers could earn a gross income of ₹ 2,30,615.3 ha-1. The net farm incomes over Cost $\mathrm{C}_{3}$ become ₹ 1,94,982.76 for category-II and ₹ 1,51,641.40 for category-I farmers. Farm efficiency measures also indicated that the farmers of category-II had more financial advantage compared to category-I in respect of yardsticks like farm business income, farm investment income, farm labour income etc.
Table 5: Return possibility from pineapple farming for different categories of sample farms

\begin{tabular}{|c|c|c|c|c|}
\hline $\begin{array}{l}\text { Sl. } \\
\text { no. }\end{array}$ & $\begin{array}{c}\text { Efficiency } \\
\text { measures }\end{array}$ & Category I & Category II & Overall \\
\hline 1. & $\begin{array}{l}\text { Gross farm } \\
\text { income }\end{array}$ & $\begin{array}{c}198853.2 \\
(\$ 3314.22)\end{array}$ & $\begin{array}{c}262377.3 \\
(\$ 4372.96)\end{array}$ & $\begin{array}{c}230615.3 \\
(\$ 3843.59)\end{array}$ \\
\hline 2. & $\begin{array}{l}\text { Net farm } \\
\text { income }\end{array}$ & $\begin{array}{c}151641.4 \\
(\$ 2527.36)\end{array}$ & $\begin{array}{c}194983.1 \\
(\$ 3249.72)\end{array}$ & $\begin{array}{c}173312.2 \\
(\$ 2888.54)\end{array}$ \\
\hline 3. & $\begin{array}{l}\text { Farm busi- } \\
\text { ness income }\end{array}$ & $\begin{array}{c}169744.5 \\
(\$ 2829.08)\end{array}$ & $\begin{array}{c}220284 \\
(\$ 3671.40)\end{array}$ & $\begin{array}{c}195014.3 \\
(\$ 3250.24)\end{array}$ \\
\hline 4. & $\begin{array}{l}\text { Owned farm } \\
\text { business } \\
\text { income }\end{array}$ & $\begin{array}{c}169744.5 \\
(\$ 2829.08)\end{array}$ & $\begin{array}{c}220284 \\
(\$ 3671.40)\end{array}$ & $\begin{array}{c}195014.3 \\
(\$ 3250.24)\end{array}$ \\
\hline 5. & $\begin{array}{l}\text { Family labour } \\
\text { income }\end{array}$ & $\begin{array}{c}157637.3 \\
(\$ 2627.29)\end{array}$ & $\begin{array}{c}203844.4 \\
(\$ 3397.41)\end{array}$ & $\begin{array}{c}180740.8 \\
(\$ 3012.35)\end{array}$ \\
\hline 6. & $\begin{array}{l}\text { Farm invest- } \\
\text { ment income }\end{array}$ & $\begin{array}{c}163748.6 \\
(\$ 2729.14)\end{array}$ & $\begin{array}{c}211422.7 \\
(\$ 523.71)\end{array}$ & $\begin{array}{c}187585.6 \\
(\$ 3126.43)\end{array}$ \\
\hline 7. & \multicolumn{4}{|c|}{ Output/Input ratio } \\
\hline i). & $\begin{array}{c}\text { Over total } \\
\operatorname{cost} A_{1}\end{array}$ & 6.83 & 6.23 & 6.53 \\
\hline ii). & $\begin{array}{l}\text { Over paid } \\
\text { out } \operatorname{cost} \mathrm{C}_{3}\end{array}$ & 4.21 & 3.89 & 4.05 \\
\hline
\end{tabular}

Figures in parentheses indicate value in $\$$ form, 1US $\$=₹ 60$ $(12 / 7 / 2014)$.

Findings from the same table also present the estimated output input ratios for the two farming categories. Values of output-input ratios had been worked out by considering (i) Cost $\mathrm{A}_{1}$ and (ii) Cost $\mathrm{C}_{3}$ which stands at 6.83 and 4.21 for category-I and 6.23 and 3.89 for category-II farmers. This implies category-I farmers got better financial advantage over category-II farmers.

\section{d. Estimation of resource use efficiency}

Production function analysis had been carried out to trace out the important factors of pineapple production with the help of Cobb Douglas production function and the result had been depicted in (Table 6). Relatively higher values $(>0.97)$ of adjusted co-efficient of multiple determinations $\left(\bar{R}^{2}\right)$ in all the cases confirm the validity/justification of 4 explanatory variables namely, sucker $\left(\mathrm{X}_{1}\right)$, manure and fertilizer $\left(\mathrm{X}_{2}\right)$, plant protection chemical $\left(\mathrm{X}_{3}\right)$ and human labour $\left(\mathrm{X}_{4}\right)$ in influencing pineapple productivity. Also, the elasticity of production was found $>1.00$ in all the categories indicating possibility of increasing returns to scale.

The technical co-efficients for manure and fertilizer $\left(X_{2}\right)$ and plant protection chemicals $\left(\mathrm{X}_{3}\right)$ inputs in case of category-I turned out to be positive and statistically significant. It gives an indication that $1 \%$ increase in the expenditure of each manure and fertilizer and plant protection chemical, on an 


\begin{tabular}{|c|c|c|c|c|c|c|c|c|c|}
\hline \multirow[b]{2}{*}{$\begin{array}{l}\text { Farm } \\
\text { category }\end{array}$} & \multirow[b]{2}{*}{$\begin{array}{l}\text { No. } \\
\text { of obs. }\end{array}$} & \multirow[b]{2}{*}{$\begin{array}{c}\text { Constant } \\
\text { term }\end{array}$} & \multicolumn{4}{|c|}{ Input coefficients } & \multirow[b]{2}{*}{$\overline{\mathrm{R}}^{2}$} & \multirow[b]{2}{*}{$\sum$ bi } & \multirow[b]{2}{*}{ F-value } \\
\hline & & & $\begin{array}{c}\mathrm{X}_{1} \\
\text { (Sucker) }\end{array}$ & $\begin{array}{c}\mathrm{X}_{2} \\
\text { (Manure and } \\
\text { fertilizer) }\end{array}$ & $\begin{array}{c}\mathrm{X}_{3} \\
\text { (Plant protection) }\end{array}$ & $\begin{array}{c}\mathrm{X}_{4} \\
\text { (Humn labour) }\end{array}$ & & & \\
\hline Category I & 67 & 6.958 & $-.485^{\mathrm{NS}}$ & $0.411^{* *}$ & $1.474^{*}$ & $-0.221^{*}$ & 0.98 & 1.178 & $765.63^{*}$ \\
\hline Category II & 33 & 4.586 & $0.362^{*}$ & $0.254^{* *}$ & $0.883^{*}$ & $-0.322^{*}$ & 0.98 & 1.17 & $656.64^{*}$ \\
\hline Overall & 100 & 5.822 & $0.235^{* *}$ & $0.087 \mathrm{NS}$ & $1.114^{* *}$ & $-0.326^{* *}$ & 0.99 & 1.110 & $722.135^{*}$ \\
\hline
\end{tabular}

${ }^{* *}$ Significant at $1 \%$ level; ${ }^{*}$ Significant at $5 \%$; NS: Non-significant

average, would increase the output of pineapple by 0.41 and $1.47 \%$ respectively, by taking one input at a time and keeping other inputs constant. Similarly, for category-II sample farms, technical co-efficient of sucker, manure and fertilizer and plant protection chemicals were found statistically significant (sucker, plant protection chemicals at $1 \%$ and manure and fertilizer at $5 \%$ probability level). It means that a $1 \%$ increase in the expenditure of these inputs on an average increased the output by $0.36,0.25$ and $0.88 \%$ respectively. But, both in category-I, category-II the technical coefficient of input like human labour is found to be statistically significant and negative. It indicates decrease in the gross return due to the increase in the use of the human labour resource. This negative input coefficient may be due to excess use of human labour input, hence its reduction/decrease in application is required.

\begin{tabular}{lccc}
\hline \multicolumn{3}{l}{$\begin{array}{l}\text { Table 7 : Marginal Value Productivity to Factor Cost ratio } \\
\text { in pineapple cultivation }\end{array}$} \\
\hline Category & \multicolumn{2}{c}{$\begin{array}{l}\text { Ratio between Value of Marginal } \\
\text { Poductivity (MVP) and Factor Cost }\end{array}$} \\
\cline { 2 - 4 } & Sucker & $\begin{array}{c}\text { Manure and } \\
\text { fertilizer }\end{array}$ & $\begin{array}{c}\text { Plant protec- } \\
\text { tion chemical }\end{array}$ \\
\hline Category I & - & 2.29 & 8.49 \\
Category II & 2.07 & 1.51 & 5.62 \\
Overall & 1.27 & 0.48 & 6.22 \\
\hline
\end{tabular}

On the other hand, in category-I, the input co-efficient of sucker was found to be negative and non significant. In overall farms, the coefficient of sucker and plant protection are found to be positive and significant at $5 \%$ probability level. It indicates, a $1 \%$ increased in the expenditure of sucker and plant protection, on an average the output increases by 0.23 and $1.11 \%$ respectively by taking one input a time and keeping other inputs constant. The regression coefficient of human labour is found to be negative but significant at $5 \%$. It indicates decrease in the gross return due to the increase in the use of the human labour resource. This negative regression coefficient may be due to excess use of human labour input, hence reduction / decrease is required.
Table 7 reveals that the marginal value productivity and factor cost ratios of plant protection chemicals is more than unity in both the categories and on an average, additional cost of one rupee in plant protection may bring an additional return of ₹ 6.22. Similarly, additional investment of one rupee for planting materials (sucker) and manures and fertilizer had brought additional return of ₹ 1.27 and ₹ 0.48 respectively. These are more than unity, implying that increasing use of this resource will bring more income to the farmers. Since, excessive use of human labour reduced the revenue substantially (as per the value in Table 6), human labour, though a very important factor, had been deliberately omitted from input use efficiency analysis. It implies that pineapple growing farmers are using these inputs excessively.

\section{Conclusion}

The pineapple can be good economic activity of Manipur. Farmers can earn net income of ₹ 1,73,312.20 (\$2888.54) $\mathrm{ha}^{-1}$. with a benefit-cost ratio of 4.05 . Small farmers (category-I) were found more beneficial compared to big farmers (CategoryII). Judicious use of sucker, plant protection chemicals, manures and fertilizers were found to have good and positive impact on production and net return. Use of excess human labour made the farming less remunerative which advocates engagement of labour at optimal level.

\section{References}

Adinya, I.B., Afu, S.M., Ijoma, J.U., 2010. Economic meltdown and decline in pineapple production: Determinant of production inefficiency of pineapple-based alley cropping practices in Cross River State, Nigeria. The Journal of Animal and Plant Sciences 20(2), 107-116.

Anupant, P., Chairidchal, P., Kongswat, A., Isawilanon, S., Subhadrabandhu, S., Vasunun, S., Siripat, S., 2000. The pineapple industry in Tailand. Proceedings of the Third International Pineapple Symposium, Pattaya, Thailand, 17-20 November 1998. Acta-Horticulturae 529, 99107.

Chen T.P., Yang S.H., Pan T.F., 2001. A study on the technical efficiency of pineapple farms in Taiwan. Journal of 
Agricultural Research of China 50(3), 88-97.

Economic Survey Manipur, 2012-13. Directorate of Economics and Statistics, Government of Manipur, 73.

Indian Horticulture Database, 2011. National Horticulture Board, Ministry of Agriculture, Government of India, Department of Agriculture and Cooperation, 106-113.

Kahlon, A.S., Karam Singh., 1992. Economics of Farm Management in India, Theory and Practice. Allied publisher Ltd. 88-90.

Kale, N.K., D.S. Navadkar., A.V. Gavali., D.L. Sale., 2005. Resource Use Structure and Efficiency in Chille
Cultivation in Thane Distric of Konkan Region. Indian Journal of Agricultural Economics 60(30), 528-529.

Model N.S., 1999. Profitability of pineapple grown in Rio Grande do Sul under different Levels of technology. Pesquisa-Agropecuaria-Gaucha 5(2), 217-228.

Sulaiman, S.F.M., Subhadrabandhu, S., Chairidchai, P., 2000. Pineapple production and research in Sri Lanka. ActaHorticulturae 529, 89-92.

Yacob, A., 2010. Global Overview and trade of the pineapple industry. The $7^{\text {th }}$ International Pineapple Symposium, Malaysia, 41. 